\title{
Muscarinic Enhancement of R-Type Calcium Currents in Hippocampal CA1 Pyramidal Neurons
}

\author{
Chao Tai, ${ }^{1 *}$ J. Brent Kuzmiski, ${ }^{1,2 *}$ and Brian A. MacVicar ${ }^{1}$ \\ ${ }^{1}$ Brain Research Center, Department of Psychiatry, University of British Columbia, Vancouver, British Columbia V6T 2B5, Canada, and ${ }^{2 H o t c h k i s s ~ B r a i n ~}$ \\ Institute, Calgary, Alberta T2N 4N1, Canada
}

The "toxin-resistant" R-type $\mathrm{Ca}^{2+}$ channels are expressed widely in the CNS and distributed mainly in apical dendrites and spines. They play important roles in regulating signal transduction and intrinsic properties of neurons, but the modulation of these channels in the mammalian CNS has not been studied. In this study we used whole-cell patch-clamp recordings and found that muscarinic activation enhances R-type, but does not affect T-type, $\mathrm{Ca}^{2+}$ currents in hippocampal CA1 pyramidal neurons after N, P/Q, and L-type Ca ${ }^{2+}$ currents selectively were blocked. $\mathrm{M}_{1} / \mathrm{M}_{3}$ cholinergic receptors mediated the muscarinic stimulation of R-type Ca ${ }^{2+}$ channels. The signaling pathway underlying the R-type enhancement was independent of intracellular $\left[\mathrm{Ca}^{2+}\right]$ changes and required the activation of a $\mathrm{Ca}^{2+}$-independent PKC pathway. Furthermore, we found that the enhancement of R-type $\mathrm{Ca}^{2+}$ currents resulted in the de novo appearance of $\mathrm{Ca}^{2+}$ spikes and in remarkable changes in the firing pattern of R-type $\mathrm{Ca}^{2+}$ spikes, which could fire repetitively in the theta frequency. Therefore, muscarinic enhancement of R-type $\mathrm{Ca}^{2+}$ channels could play an important role in modifying the dendritic response to synaptic inputs and in the intrinsic resonance properties of neurons.

Key words: acetylcholine; muscarinic; R-type calcium spikes; $\alpha 1 \mathrm{E}$ calcium subunits; $\mathrm{Ca}_{\mathrm{V}} 2.3$; T-type calcium currents; theta; epilepsy; oscillations; hippocampus

\section{Introduction}

R-type voltage-sensitive $\mathrm{Ca}^{2+}$ currents originally were identified as the high voltage-activated (HVA) $\mathrm{Ca}^{2+}$ currents that were resistant to the antagonists $\omega$-conotoxin MVIIC, $\omega$-conotoxinGVIA, $\omega$-agatoxin IVA, and the dihydropyridines (Zhang et al., 1993; Randall and Tsien, 1995). In hippocampal CA1 pyramidal neurons the R-type voltage-sensitive $\mathrm{Ca}^{2+}$ channels (VSCCs) are highly expressed in distal dendrites (Christie et al., 1995; Magee and Johnston, 1995) and are thought to be primarily responsible for $\mathrm{Ca}^{2+}$ influx in dendrites and spines (Sabatini and Svoboda, 2000; Yasuda et al., 2003). R-type $\mathrm{Ca}^{2+}$ currents are involved in generating action potential bursts and afterdepolarizations (Magee and Carruth, 1999; Metz et al., 2005) and in the induction of synaptic plasticity (Isomura et al., 2002; Breustedt et al., 2003; Dietrich et al., 2003; Yasuda et al., 2003).

Modulation of R-type $\mathrm{Ca}^{2+}$ currents could have profound impacts on dendritic excitability via modification of intrinsic firing patterns and the integrative properties of dendrites. Brief trains of backpropagating action potentials have been shown to depress $\mathrm{Ca}^{2+}$ entry through R-type VSCCs located in dendritic spines and thereby block theta burst-induced long-term potenti-

Received March 7, 2006; revised April 11, 2006; accepted May 1, 2006.

This work was supported by the Canadian Institutes of Health Research. B.A.M. is supported by a Canada Research Chair in Neuroscience and a Distinguished Scholar award from the Michael Smith Foundation for Health Research. ${ }^{*}$ C.T. and J.B.K. contributed equally to this work.

Correspondence should be addressed to Dr. Brian A. MacVicar, Brain Research Center, Department of Psychiatry, University of British Columbia, 2211 Wesbrook Mall, Vancouver, British Columbia V6T 2B5, Canada. E-mail: bmacvica@interchange.ubc.ca.

DOI:10.1523/JNEUROSCI.1009-06.2006

Copyright $\odot 2006$ Society for Neuroscience $\quad$ 0270-6474/06/266249-10\$15.00/0 ation (LTP) (Yasuda et al., 2003). In expression systems the R-type $\mathrm{Ca}^{2+}$ currents caused by recombinant $\mathrm{Ca}_{\mathrm{V}} 2.3(\alpha 1 \mathrm{E})$ VSCCs (Piedras-Renteria and Tsien, 1998; Sochivko et al., 2002; Bannister et al., 2004) are stimulated by the activation of coexpressed muscarinic (Meza et al., 1999; Melliti et al., 2000; Bannister et al., 2004) or metabotropic glutamate receptors (mGluRs) (Stea et al., 1995). However, the modulation of R-type $\mathrm{Ca}^{2+}$ currents by muscarinic or metabotropic receptors has not been examined in native neurons in brain slices or in vivo. Therefore, we used whole-cell recordings to examine whether $\mathrm{Ca}^{2+}$ currents caused by R-type VSCCs are enhanced in hippocampal brain slices by muscarinic activation. We show that both $\mathrm{R}$-type $\mathrm{Ca}^{2+}$ currents and spikes are enhanced by the stimulation of muscarinic receptors in CA1 pyramidal neurons. This is in striking contrast to the extensively studied depression of N-, P-/Q-, and L-type $\mathrm{Ca}^{2+}$ currents by the activation of muscarinic receptors (Gahwiler and Brown, 1987; Shapiro et al., 1999, 2001; Stewart et al., 1999). Furthermore, initiation of dendritic $\mathrm{Ca}^{2+}$ spikes has been suggested to play a role in generating or shaping neuronal network oscillations (Kamondi et al., 1998; Buzsaki, 2002). Interestingly, we found that muscarinic stimulation leads to remarkable and novel changes in the R-type $\mathrm{Ca}^{2+}$ spike firing pattern. After muscarinic receptor stimulation the enhanced R-type $\mathrm{Ca}^{2+}$ spikes repetitively fired at theta frequencies $(6-10 \mathrm{~Hz})$, and blocking R-type VSCCs depressed carbachol-induced spontaneous field potential theta oscillations, suggesting that enhanced R-type calcium spikes play a role in dendritic bursting and network oscillations. Therefore, muscarinic receptor activation in hippocampal neurons will alter profoundly the dendritic integration and intrinsic resonance properties by shifting the normal 
pattern of $\mathrm{Ca}^{2+}$ entry from the slowly inactivating $\mathrm{N}-, \mathrm{P} / \mathrm{Q}-$, and L-type VSCCs to domination by the HVA rapidly inactivating R-type VSCCs.

\section{Materials and Methods}

Hippocampal slice preparation. Hippocampal slices were prepared from Sprague Dawley rats, aged postnatal days 13-16, according to standard procedures (Fraser and MacVicar, 1996). Our experiments were approved by the Canadian Council for Animal Care and the University of British Columbia Animal Care Committee. All experiments were conducted in strict accordance with National Institutes of Health Guide for the Care and Use of Laboratory Animals. Briefly, the rats were anesthetized deeply with halothane and decapitated rapidly. The brain was removed quickly, and horizontal hippocampal slices $(\sim 400 \mu \mathrm{m})$ were cut with a vibratome (VT100, Leica, Willowdale, Ontario, Canada) in chilled (0$4^{\circ} \mathrm{C}$ ) slicing solution containing the following (in mM): 75 sucrose, 87 $\mathrm{NaCl}, 25 \mathrm{NaHCO}_{3}, 25 \mathrm{D}$-glucose, $2.5 \mathrm{KCl}, 1.25 \mathrm{NaH}_{2} \mathrm{PO}_{4}, 0.5 \mathrm{CaCl}_{2}$, and $7.0 \mathrm{MgCl}_{2}, \mathrm{pH}$ 7.3. Then the slices were transferred to a storage chamber with fresh artificial CSF (ACSF) containing the following (in $\mathrm{mM}$ ): 126 $\mathrm{NaCl}, 2.5 \mathrm{KCl}, 2.0 \mathrm{MgCl}_{2}, 2.0 \mathrm{CaCl}_{2}, 1.25 \mathrm{NaH}_{2} \mathrm{PO}_{4}, 26 \mathrm{NaHCO}_{3}$, and 10 D-glucose, $\mathrm{pH} 7.3$, and were incubated at room temperature for $>1 \mathrm{~h}$ before recording. All solutions were saturated with $95 \% \mathrm{O}_{2} / 5 \% \mathrm{CO}_{2}$.

Whole-cell patch-clamp recordings. Whole-cell voltage-clamp or current-clamp recordings from CA1 neurons within hippocampal slices (Blanton et al., 1989) were obtained at room temperature $\left(22-24^{\circ} \mathrm{C}\right)$. Individual slices were transferred to a recording chamber located on an upright microscope (Axioskop, Zeiss, Oberkochen, Germany) and perfused rapidly with oxygenated ACSF $(2 \mathrm{ml} / \mathrm{min})$. Patch electrodes (3-5 $\mathrm{M} \Omega$ ) were pulled from $1.5 \mathrm{~mm}$ outer diameter thin-walled glass capillaries (150F-4, World Precision Instruments, Sarasota, FL) in three stages on a Flaming-Brown micropipette puller (model P-97, Sutter Instruments, Novato, CA) and were filled with intracellular solution containing the following (in mM): 115 Cs-methanesulphonate, 25 TEA-Cl, 10 HEPES, 1.1 EGTA, $0.1 \mathrm{CaCl}_{2}, 4 \mathrm{Mg}$-ATP, and 0.5 Na-GTP, pH 7.2. Intracellular $\left[\mathrm{Ca}^{2+}\right]$ was calculated to be $16 \mathrm{nM}$. In some experiments BAPTA was substituted for EGTA, as described. In the BAPTA experiments stable whole-cell recordings were maintained for $>15-20 \mathrm{~min}$ before recording to ensure that the BAPTA diffused into dendritic regions. R-/T-type $\mathrm{Ca}^{2+}$ currents were isolated pharmacologically by preincubating the slices in a mixture containing $\omega$-conotoxin MVIIC (2 $\mu \mathrm{M}), \omega$-conotoxin-GVIA $(2 \mu \mathrm{M})$, and $\omega$-agatoxin IVA $(0.4 \mu \mathrm{M})$ to block $\mathrm{N}$-, P-, and Q-type $\mathrm{Ca}^{2+}$ currents and cytochrome $c(0.1 \mathrm{mg} / \mathrm{ml})$ to block nonspecific toxin binding for $>1 \mathrm{~h}$ at room temperature. Nifedipine (20 $\mu \mathrm{M})$ and tetrodotoxin (TTX; $1.2 \mu \mathrm{M}$ ) were bath applied to block L-type $\mathrm{Ca}^{2+}$ currents and $\mathrm{Na}^{+}$currents, respectively. Also, $2 \mathrm{~mm} \mathrm{CsCl}$ and 1 mm 4-aminopyridine (4-AP) were bath applied to block residue $\mathrm{K}^{+}$ channels.

Membrane potentials and currents were monitored with an Axopatch 200B amplifier (Molecular Devices, Union City, CA), acquired via a Digidata 1200 series analog-to-digital interface onto a Pentium computer with Clampex 9.0 software (Molecular Devices). Data were sampled at 10 $\mathrm{kHz}$, and most were low-pass filtered (four-pole Bessel) at $1 \mathrm{kHz}$. Data were not filtered for tail current analysis. For voltage-clamp recordings the leakage and capacitive currents were subtracted by using a $\mathrm{P} /-4$ protocol (four negative correction pulses, with amplitude one-fourth of that of the test pulse). In current-clamp recordings, bridge balance and capacitance compensation were performed. Access resistance was monitored continuously, and only cells with access resistance $<20 \mathrm{M} \Omega$ were used.

Extracellular recordings. For extracellular recordings the slices were transferred to an interface chamber $\left(32-34^{\circ} \mathrm{C}\right.$; Fine Science Tools, Vancouver, British Columbia). We recorded extracellular potentials with glass micropipettes filled with ACSF (1-3 M $\Omega$ ). Recording electrodes were positioned in the CA1 pyramidal cell layer, and signals were acquired via an A-M Systems amplifier (low filter, $1.0 \mathrm{~Hz}$; high filter, 5.0 $\mathrm{kHz} ; 1000 \times)$ (model 1800 Microelectrode, A-M Systems, Sequim, WA). Before spontaneous field activity was recorded, slice viability and stability were verified by the recording of evoked field EPSPs. Glass micropipettes filled with ACSF were used to stimulate electrically the Schaffer collateral pathway $(0.03 \mathrm{~Hz})$. Stable recordings $(\sim 20 \mathrm{~min})$ with a population spike that had peak-to-peak amplitudes of $>10 \mathrm{mV}$ were used.

Reagents. TTX, $\omega$-conotoxin-GVIA, and $\omega$-agatoxin IVA were purchased from Alamone Labs (Jerusalem, Israel); $\omega$-conotoxin MVIIC from Bachem (Torrance, CA); nickel (II) chloride from J.T. Baker (Paris, $\mathrm{KY})$; pirenzepine, protein phosphatase 2 (PP2), and 2-[1-(3dimethylaminopropyl)indol-3-yl]-3-(indol-3-yl) maleimide (GF 109203x) from Tocris (Ellisville, MO); BAPTA from Molecular Probes (Eugene, OR); 3-[1-3-(amidinothio)-propyl- ${ }^{1} H$-indol-3-yl]-3-(1-methyl- ${ }^{1} H$ indol-3-yl)maleimide (Ro 31-8220), 2-[N-(2-hydroxyethyl)]-N-(4methoxybenzenesulfonyl)amino- $N$-(4-chlorocinnamyl- $N$-methylbenzylamine) (KN-93), and 12-(2-cyanoethyl)-6,7,12,13-tetrahydro13-methyl-5-oxo- ${ }^{5} \mathrm{H}$-indolo(2,3-a)pyrrolo(3,4-c)-carbazole (Go 6976) from Calbiochem (La Jolla, CA); all other reagents were purchased from Sigma (St. Louis, MO).

Data analysis. Data were analyzed with Clampfit 9.0 (Molecular Devices). In all cases Student's $t$ tests were used for statistical comparisons, with $p<0.001$ considered significant. Values are reported as the mean \pm SEM.

\section{Results}

Carbachol enhances toxin-resistant HVA R-type currents but does not affect low voltage-activated T-type $\mathrm{Ca}^{2+}$ currents We tested the hypothesis that muscarinic receptor stimulation enhances R-type VSCCs in CA1 pyramidal neurons similar to the muscarinic enhancement of recombinant $\mathrm{Ca}_{\mathrm{V}} 2.3$ VSCCs described in human embryonic kidney (HEK) 293 cells (Melliti et al., 2000; Bannister et al., 2004). We performed voltage-clamp recordings to characterize the cholinergic modulation of the toxin-resistant $\mathrm{Ca}^{2+}$ currents, which were isolated with a mixture containing TTX, nifedipine, and VSCC toxins (as described in Materials and Methods). CA1 pyramidal neurons from hippocampal slices were patch clamped with a $\mathrm{Cs}^{+}$- and $\mathrm{TEA}^{+}$based intracellular solution to suppress $\mathrm{K}^{+}$channels and to minimize muscarinic-mediated effects on $\mathrm{K}^{+}$channels. The ACSF contained $\mathrm{Cs}^{+}$and 4-AP to block potassium current and to increase the space-clamp efficiency. Under these conditions we observed an enhancement of HVA $\mathrm{Ca}^{2+}$ currents. In the presence of the VSCC blocker mixture toxin-resistant low (T-type) and high (R-type) voltage-activated transient $\mathrm{Ca}^{2+}$ currents were recorded in all cells (Fig. 1A). The classification of currents was based on the potentials for activation, toxin resistance, and $\mathrm{Ni}^{2+}$ sensitivity. Only the HVA R-type current was enhanced dramatically after the application of carbachol $(n=13)$ (Fig. $1 B)$. This carbachol-mediated stimulation was reversible $(n=6)$ (Fig. $1 C)$, and the currents were sensitive to $50 \mu \mathrm{M} \mathrm{Ni}^{2+}(n=5)$ (Fig. 1D). Strikingly, the $I-V$ curve of the $\mathrm{Ca}^{2+}$ currents showed that the T-type component (observed as a shoulder in the $I-V$ at -60 to $-30 \mathrm{mV}$ ) was not affected, whereas the peak of the R-type current was enhanced dramatically in carbachol (Fig. $1 E$ ). The averaged $I-V$ curve before and after carbachol treatment is shown in Figure $2 A(n=7)$. The peak amplitudes of T-type and R-type currents are plotted in Figure $2 B$, showing that the T-type component did not change ( $99.6 \pm 2 \%$ of control; $p=0.76 ; n=10)$, whereas the R-type component increased significantly ( $154 \pm 4 \%$ of control; $p<0.0001 ; n=13)$. The example traces for T-type and R-type are shown in Figure 2C. The enhanced amplitude of the R-type $\mathrm{Ca}^{2+}$ current was associated consistently with a significant shift of the voltage-dependent activation curve to negative potentials, with a change in the voltage for half-maximal activation $\left(V_{\text {act }}\right)\left(\Delta V_{\text {act }}=\right.$ $-4.2 \pm 0.7 \mathrm{mV} ; p<0.001 ; n=7$ ) (Fig. 2D). The enhancement of $\mathrm{R}$-type $\mathrm{Ca}^{2+}$ currents was reversible and blocked by atropine ( 1 $\mu \mathrm{M})$, demonstrating that it was attributable to muscarinic receptor activation by carbachol $(n=6)$ (Fig. $2 E)$. Pooled data for 

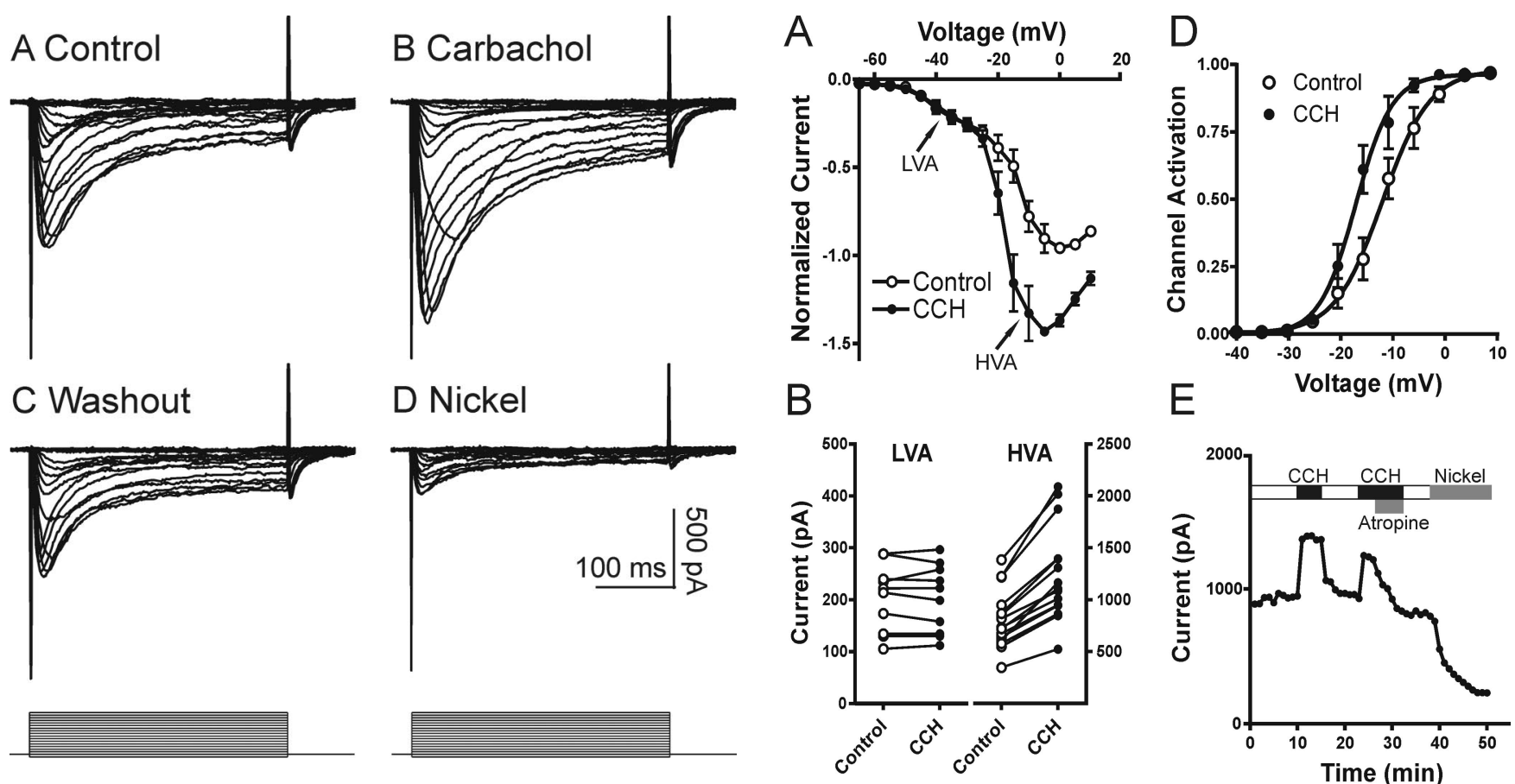

E
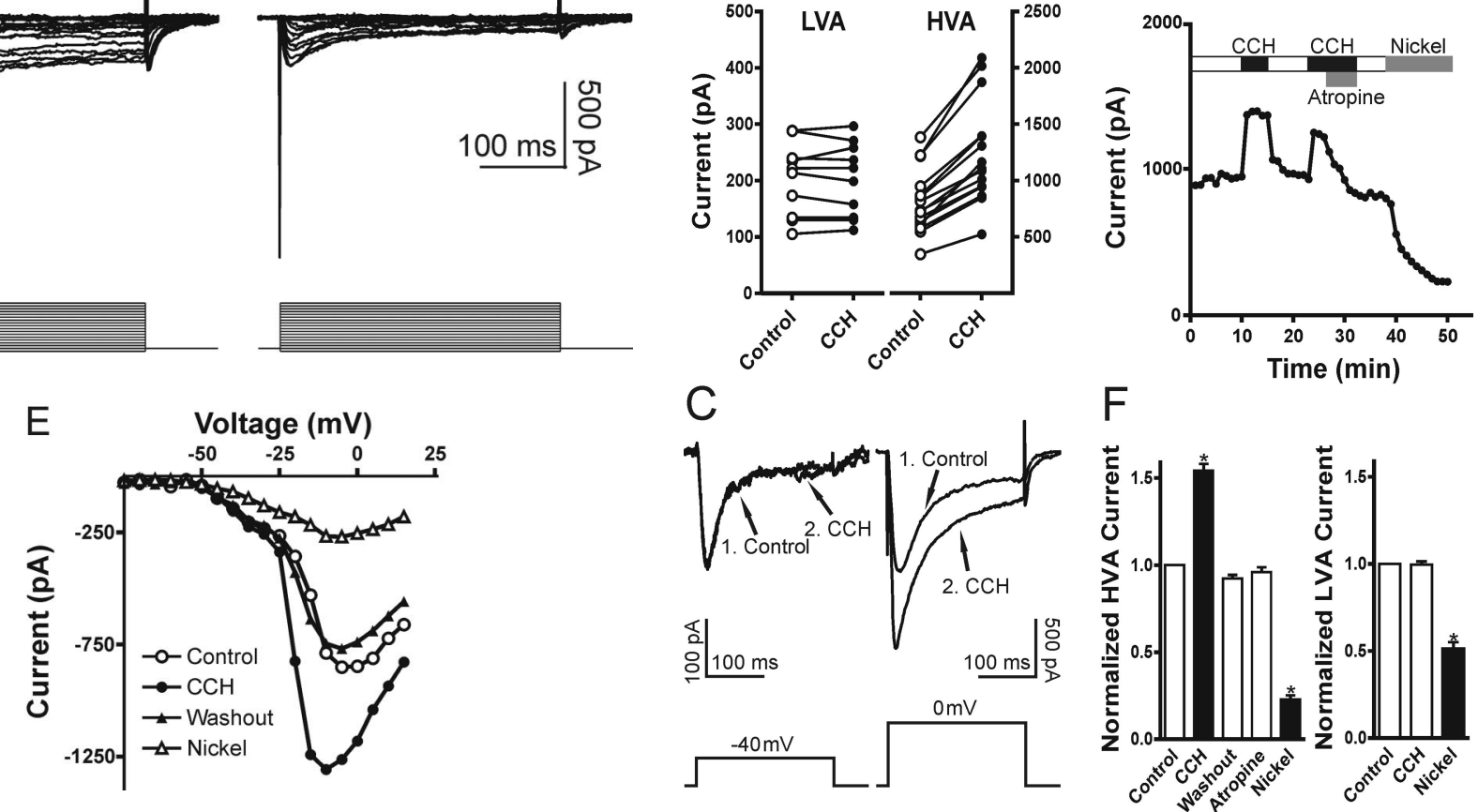

Figure 1. Carbachol enhances toxin-resistant $\mathrm{HVAC}^{2+}$ currents. Whole-cell patch-clamp recordings were performed with a $\mathrm{Cs}^{+}$- and TEA ${ }^{+}$-based intracellular solution. Slices were preincubated with toxins (as described in Materials and Methods) and perfused with TTX (1.2 $\mu \mathrm{M})$ and nifedipine $(20 \mu \mathrm{M}) . \boldsymbol{A}$, In voltage-clamp mode, a well clamped $\mathrm{Ca}^{2+}$ current was recorded. $\boldsymbol{B}$, The current was enhanced by the application of carbachol (30 $\mu \mathrm{M})$. This enhancement was reversible $(\boldsymbol{C})$ and sensitive to $\mathrm{Ni}^{2+}(50 \mu \mathrm{m} ; \boldsymbol{D})$. $\boldsymbol{E}, \mathrm{I}-V$ relationships of this cell before and after treatment, showing that the T-type component (observed as a shoulder at -60 to -30 $\mathrm{mV}$ in the $I-V$ ) was not affected, whereas the peak of the R-type current was enhanced dramatically in carbachol (CCH).

muscarinic modulation of R-type and T-type VSCCs are shown in Figure $2 F$ (for each group, $n \geq 5$ ). These results suggest that, in CA1 pyramidal neurons, muscarinic activation enhances only the HVA R-type $\mathrm{Ca}^{2+}$ currents, but not the low voltage-activated (LVA) T-type $\mathrm{Ca}^{2+}$ currents.

To verify additionally that T-type $\mathrm{Ca}^{2+}$ currents were not modulated by muscarinic activation, we first blocked all HVA $\mathrm{Ca}^{2+}$ currents by perfusing $30 \mu \mathrm{M} \mathrm{Cd}{ }^{2+}$ instead of the strategy used above with toxins and nifedipine. This is effective for isolating T-type $\mathrm{Ca}^{2+}$ currents, because the HVA Ca ${ }^{2+}$ currents are much more sensitive to low concentrations of $\mathrm{Cd}^{2+}$ (Ozawa et al., 1989; Mogul and Fox, 1991; Avery and Johnston, 1996; Huguenard, 1996). Under these conditions a LVA component was observed with no apparent HVA component $(n=7)$ (Fig. $3 A)$. Application of $\mathrm{Cd}^{2+}(30 \mu \mathrm{M})$ only slightly decreased T-type $\mathrm{Ca}^{2+}$ currents $(91 \pm 6 \%$ of control; $p=0.68 ; n=7)$ (Fig. $3 B, C)$, whereas the R-type $\mathrm{Ca}^{2+}$ currents were abolished $(11 \pm 7 \%$ of

Figure 2. Muscarinic activation enhances R-type, but not T-type, $\mathrm{Ca}^{2+}$ current. $A-C, \mathrm{HVA}$, but not LVA, component is stimulated by muscarinic activation. The mean $I-V$ relationships before and after carbachol (CCH) treatment from seven cells are shown in $A$. The peak current amplitudes and sample traces are shown in $\boldsymbol{B}, \boldsymbol{C}(1$, Control; $2, \mathrm{CCH}) . \boldsymbol{D}$, The $\mathrm{Ca}^{2+}$ channel activation curve analyzed from peak currents and estimated conductance is shifted significantly to the left. The result was similar when tail currents were analyzed (data not shown). The result was fit with a Boltzmann equation. $\boldsymbol{E}$, Time course of the peak $\mathrm{HVA} \mathrm{Ca}^{2+}$ current shows that carbachol (CCH) stimulation of R-type VSCCs is reversible and is blocked by the muscarinic receptor antagonist atropine $(1 \mu \mathrm{M}) . \boldsymbol{F}$, Mean data for the muscarinic modulation of the LVA and HVA $\mathrm{Ca}^{2+}$ current components. All recordings were obtained in TTX and VSCC blockers (as described in Materials and Methods). Error bars indicate the mean \pm SEM. Asterisk indicates significant change $\left({ }^{*} p<0.001\right)$.

control; $p<0.0001 ; n=7$ ) (Fig. $3 B, D$ ). We then tested the modulation of $\mathrm{Cd}^{2+}$-isolated T-type $\mathrm{Ca}^{2+}$ currents by muscarinic receptor activation. In agreement with our results described above, we did not observe any significant alteration of the isolated T-type $\mathrm{Ca}^{2+}$ currents by carbachol $(104 \pm 7 \%$ of control; $p=$ $0.57 ; n=6$ ) (Fig. $3 E-G$ ). The averaged $I-V$ curves for the effects of carbachol on T-type $\mathrm{Ca}^{2+}$ currents are shown in Figure $3 F$. Application of $\mathrm{Ni}^{2+}(50 \mu \mathrm{M})$ suppressed this current by $\sim 50 \%$ $(n=5 ; p<0.0001)$ (Fig. $3 E, G)$. Because low micromolar concentrations of $\mathrm{Ni}^{2+}$ block only $\alpha 1 \mathrm{H}$ subunits, but not $\alpha 1 \mathrm{G}$ or $\alpha 1 \mathrm{I}$ (Klockner et al., 1999; Lee et al., 1999; Perez-Reyes, 2003), our results suggest the existence of multiple subunits of T-type VSCCs in CA1 pyramidal neurons, which is consistent with previous in situ hybridization work (Talley et al., 1999). These results 
A
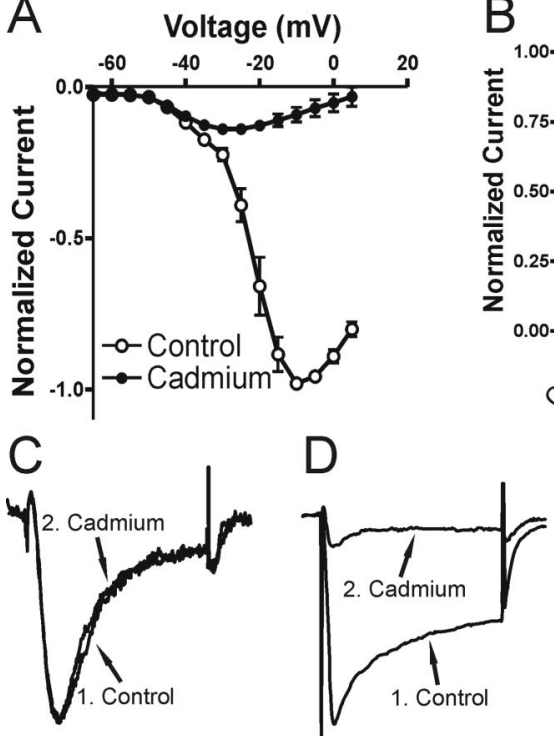

部 $100 \mathrm{~ms}$

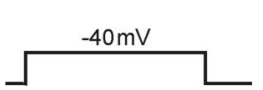

$\mathrm{F}$
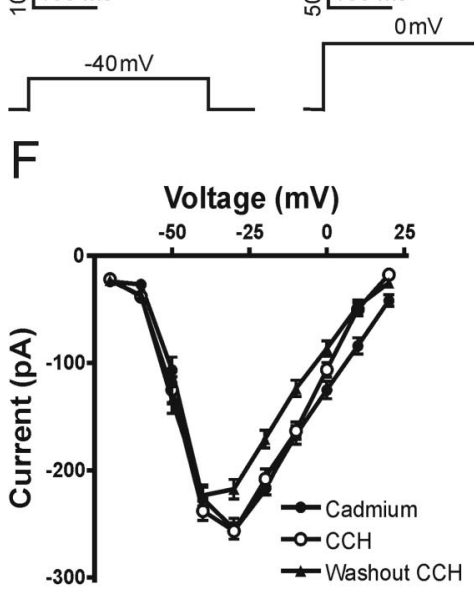

$\mathrm{G}$

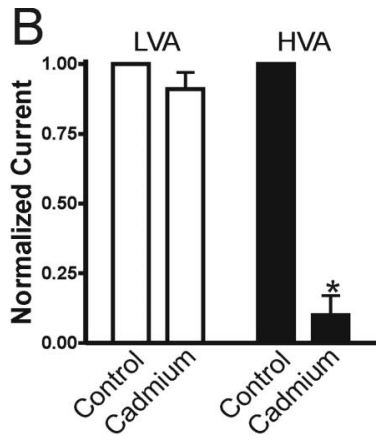

$\mathrm{E}$

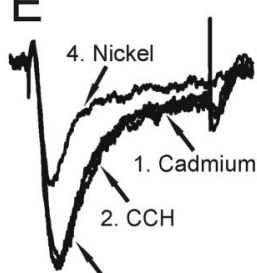

3. Washout $\mathrm{CCH}$
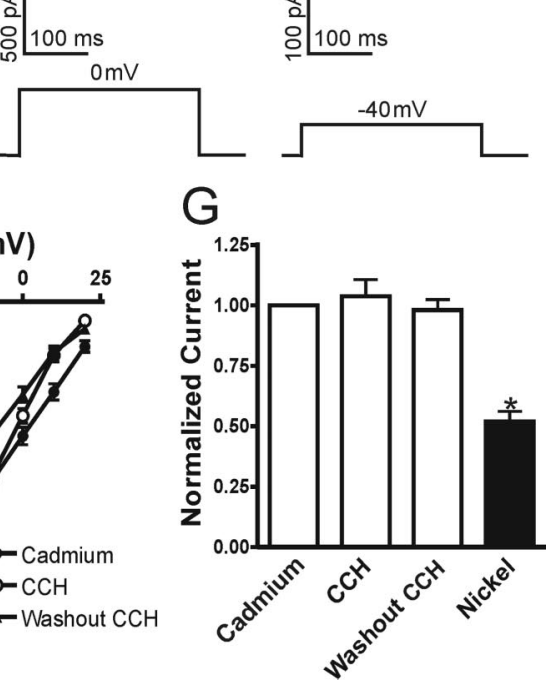

Figure 3. T-type $\mathrm{Ca}^{2+}$ current is not affected in carbachol. $\mathrm{Cd}^{2+}(30 \mu \mathrm{m})$ was used to isolate the LVAVSCCs. $A$, Mean $/-V$ curve of $\mathrm{Cd}^{2+}$-isolated $\mathrm{Ca}^{2+}$ current $(n=7)$. Mean data for $\mathrm{Cd}^{2+}$ effects in $\boldsymbol{B}$ show that the LVA component was decreased slightly, whereas the HVA component was nearly diminished by $\mathrm{Cd}^{2+}(30 \mu \mathrm{M}) . C, D$, Sample traces for LVA and HVA currents before $\left(1\right.$, Control) and after $\left(2\right.$, Cadmium) $\mathrm{Cd}^{2+}$ treatment are shown. $\boldsymbol{E}$, The $\mathrm{Cd}^{2+}$. isolated LVA Ca ${ }^{2+}$ current (1, Cadmium) was not affected by carbachol $(2, \mathrm{CCH})$ or during washout (3, Washout $\mathrm{CCH}$ ) but was blocked partially by subsequent treatment with $\mathrm{Ni}^{2+}(4$, Nickel; $50 \mu \mathrm{m})$. $\boldsymbol{F}$, Mean I-V curves for effects of carbachol (CCH and Washout $(\mathrm{CH})$ on the $\mathrm{Cd}^{2+}$-isolated T-type $\mathrm{Ca}^{2+}$ currents $(n=5)$. $\mathbf{G}$, Mean data for muscarinic modulation of $\mathrm{Cd}^{2+}$-isolated T-type VSCCs (for each group, $n \geq 5$ ). Error bars indicate the mean \pm SEM. Asterisk indicates significant change $\left({ }^{*} p<0.001\right)$.

confirmed that, in CA1 pyramidal neurons, muscarinic activation had no effect on T-type $\mathrm{Ca}^{2+}$ currents.

$\mathrm{M}_{1} / \mathrm{M}_{3}$ cholinergic receptors mediate muscarinic stimulation of R-type VSCCs

The ability of atropine $(1 \mu \mathrm{M})$ to block the stimulation of carbachol in R-type $\mathrm{Ca}^{2+}$ currents demonstrates that muscarinic receptors mediate this enhancement. In the hippocampus four of the muscarinic subtypes $\left(\mathrm{M}_{1}-\mathrm{M}_{4}\right)$ are expressed abundantly (Vilaro et al., 1993; Levey et al., 1995; Rouse et al., 1999). To determine further the muscarinic receptor subtypes involved in the enhancement of R-type $\mathrm{Ca}^{2+}$ currents, we tested the antagonists and agonists for $\mathrm{M}_{1}-\mathrm{M}_{4}$ cholinergic receptors. We found
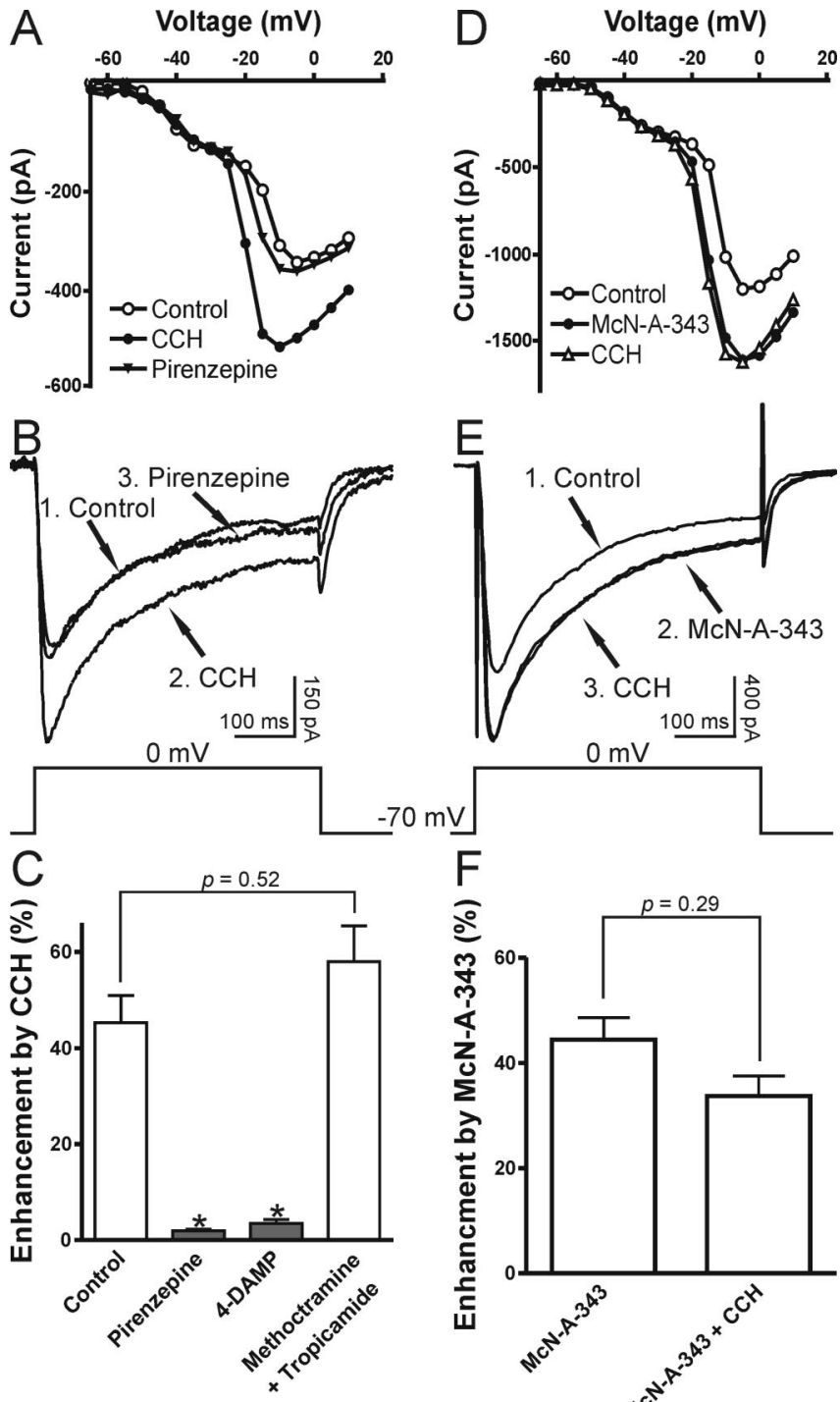

$-70 \mathrm{mV}$

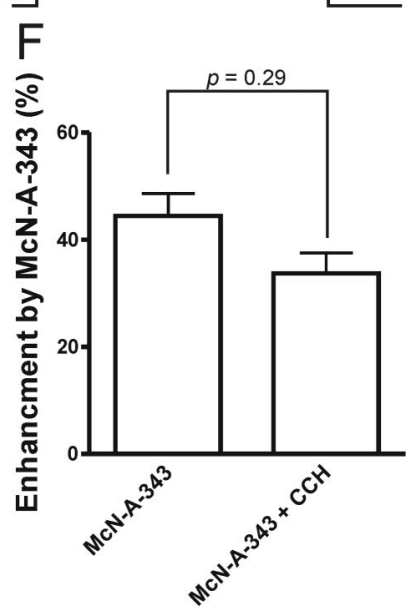

Figure 4. $M_{1} / M_{3}$ muscarinic subtypes mediate the stimulation of R-type $\mathrm{Ca}^{2+}$ current. $A-C$, The $M_{1}$ antagonist pirenzepine $(1 \mu \mathrm{M})$ reversed the stimulation of R-type VSCCs by carbachol (CCH). I-V curves and sample traces are shown in $A, B$ (1, Control; 2 , CCH; 3, Pirenzepine). C, Mean data for the effects of pirenzepine (1 $\mu \mathrm{M}), 4-D A M P\left(1 \mu \mathrm{M} ; \mathrm{M}_{1} / \mathrm{M}_{3}\right.$ antagonist), and methoctramine plus tropicamide ( $1 \mu \mathrm{m} ; \mathrm{M}_{2}$ and $\mathrm{M}_{4}$ antagonists) on the enhancement of $R$-type VSCCS. D-F, M a a gonist McN-A-343 $(100 \mu \mathrm{M})$ mimicked and occluded the stimulation of R-type VSCCs by carbachol (CCH). I-V curves and sample traces are shown in $\boldsymbol{D}, \boldsymbol{E}(1$, Control; $2, \mathrm{McN}$ A-343; $3,(\mathrm{CH}) . \boldsymbol{F}$, Mean data for the effects of McN-A-343 and the subsequent application of carbachol (CCH) on R-type VSCCS. All recordings were obtained in TTX and VSCC blockers (as described in Materials and Methods). Error bars indicate the mean \pm SEM. Asterisk indicates significant change $\left({ }^{*} p<0.001\right)$.

that both pirenzepine ( $1 \mu \mathrm{M} ; n=5)$, a $\mathrm{M}_{1}$-specific antagonist, and 4-diphenylactoxy- $N$-methylpiperidine (4-DAMP; $1 \mu \mathrm{M} ; n=$ 4), an antagonist with equal affinity to both $\mathrm{M}_{1}$ and $\mathrm{M}_{3}$ receptors, could reverse the carbachol enhancement of R-type $\mathrm{Ca}^{2+}$ currents (Fig. $4 A-C$ ). In contrast, the $\mathrm{M}_{2} / \mathrm{M}_{4}$ antagonists methatropine $(1 \mu \mathrm{M})$ and tropicamide $(1 \mu \mathrm{M})$ had no effect $(n=5)$ (Fig. $4 C$ ). To confirm the involvement of $\mathrm{M}_{1} / \mathrm{M}_{3}$ subtypes, we tested the $\mathrm{M}_{1}$ agonist 4- $\mathrm{N}$-[3-chlorophenyl]carbamoyloxy-2-butynyltrimethylammonium chloride (McN-A-343; $100 \mu \mathrm{M})$. We found that McN-A-343 mimicked the carbachol-mediated enhancement of R-type $\mathrm{Ca}^{2+}$ currents $(n=6)$, and, when applied first, McN-A-343 occluded additional enhancement by the subsequent treatment of carbachol (30 $\mu \mathrm{M} ; n=4)$ (Fig. $4 D-F)$. Thus 
the muscarinic enhancement of R-type $\mathrm{Ca}^{2+}$ currents is mediated by $M_{1} / M_{3}$ subtypes.

\section{Muscarinic modulation of R-type VSCCs requires a $\mathrm{Ca}^{2+}$-independent PKC pathway}

In recombinant systems the stimulation of $\mathrm{Ca}_{\mathrm{V}} 2.3 \mathrm{Ca}^{2+}$ currents is dependent on phosphorylation that is mediated by a pathway coupled to a pertussis toxin-insensitive $\mathrm{G} \alpha$ subunit $\left(\mathrm{G} \alpha_{\mathrm{q} / 11}\right)$ (Bannister et al., 2004). $M_{1} / M_{3}$ receptors couple to $G \alpha_{\mathrm{q}}$ subunits to stimulate phospholipase $\mathrm{C} \beta_{1}$ (PLC $\left.\beta_{1}\right)$, which initiates phosphatidylinositol 4,5-bisphosphate $\left(\mathrm{PIP}_{2}\right)$ turnover. This leads to the production of diacylglycerol $(\mathrm{DAG})$ and $\mathrm{IP}_{3}$-mediated $\mathrm{Ca}^{2+}$ release, which in turn activates protein kinase $\mathrm{C}$ (PKC). Basically, there are three groups of PKCs: the $\mathrm{Ca}^{2+}$ - and DAG-dependent isoforms (group I), the $\mathrm{Ca}^{2+}$-independent but DAG-dependent isoforms (group II), and the atypical isoforms (group III). We examined the signaling mechanisms underlying the enhancement of R-type $\mathrm{Ca}^{2+}$ currents by first testing the $\mathrm{Ca}^{2+}$ dependence and then by examining the sensitivity to different PKC inhibitors. A high concentration of high-affinity $\mathrm{Ca}^{2+}$ chelator BAPTA (10 mM) was used in the pipette solution, which has proved to be sufficient to block completely the carbacholinduced plateau potentials or tail currents in our lab (Fraser and MacVicar, 1996; Kuzmiski and MacVicar, 2001). We found that $10 \mathrm{~mm}$ BAPTA could not prevent the carbachol enhancement of R-type VSCCs $(n=5)$ (Fig. $5 A, D)$, suggesting it involves a $\mathrm{Ca}^{2+}$ independent pathway. To investigate the potential involvement of PKC in the enhancement of R-type VSCCs, we preincubated slices for $>30$ min with the broad spectrum PKC antagonists GF 109203x (10 $\mu \mathrm{M} ; n=5)$ or Ro 31-8220 (10 $\mu \mathrm{M} ; n=5)$. In the presence of these PKC antagonists carbachol did not enhance R-type $\mathrm{Ca}^{2+}$ currents (Fig. $5 B, E$ ), suggesting that PKCs are involved in this modulation. Interestingly, in the presence of PKC inhibitors (GF 109203x or Ro 8332) a significant suppression of R-type $\mathrm{Ca}^{2+}$ currents was observed by muscarinic stimulation (Fig. $5 B, E$ ). This inhibitory effect probably results from the activation of pertussis toxin-sensitive G-protein-coupled $\mathrm{M}_{2} / \mathrm{M}_{4}$ receptors and G $\beta \gamma$ subunit-mediated inhibition (Meza et al., 1999; Bannister et al., 2004). Because we observed a stable enhancement of R-type currents in normal conditions, we did not study this inhibitory effect further. To determine which group of PKCs is involved, we applied the specific group I $\left(\mathrm{Ca}^{2+}\right.$-dependent $)$ PKC inhibitor Go $6976(10 \mu \mathrm{M} ; n=5)$. Application of Go 6976 did not block the carbachol-mediated enhancement of R-type $\mathrm{Ca}^{2+}$ currents (Fig. 5C,E). $\mathrm{Ca}^{2+} /$ calmodulin-dependent protein kinase II (CaMKII) and Src-family signaling pathways also have been reported to be involved in some muscarinic-activated pathways. However, we found that inhibitors of CaMKII (KN-93, 10 $\mu \mathrm{M} ; n=6)$ and Src-kinase (PP2, $10 \mu \mathrm{M} ; n=5$ ) had no effect on the muscarinic stimulation of R-type $\mathrm{Ca}^{2+}$ currents at concentrations that have been reported to be effective in brain slices (Fig. 5E) (Zhao et al., 2004; Grishin et al., 2005; Huang et al., 2005). This pattern of sensitivity to $\mathrm{PKC}$ antagonists and insensitivity to BAPTA suggests the involvement of $\mathrm{Ca}^{2+}$-independent PKCs in the muscarinic effect on R-type $\mathrm{Ca}^{2+}$ currents.

\section{Muscarinic enhancement of R-type $\mathrm{Ca}^{2+}$ spikes}

Current-clamp recordings also were performed to characterize the cholinergic modulation of the toxin-resistant $\mathrm{Ca}^{2+}$ spikes. CA1 pyramidal neurons from hippocampal slices also were patch-clamped with a $\mathrm{Cs}^{+}$-based intracellular solution to suppress $\mathrm{K}^{+}$channels and to minimize muscarinic-mediated effects on $\mathrm{K}^{+}$channels. When recordings were obtained from CA1 neu-
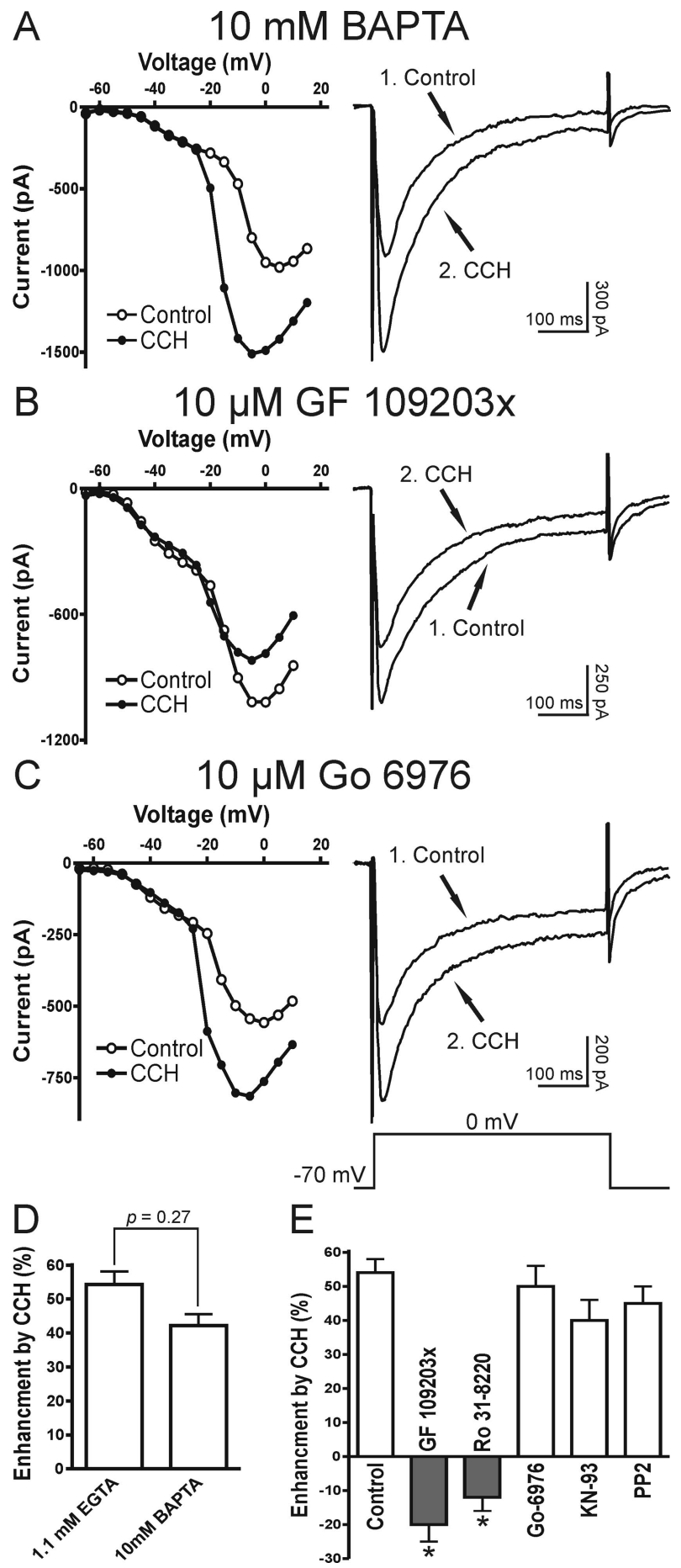

Figure 5. Mechanisms underlying the muscarinic stimulation of R-type VSCCS. $A, \mathrm{Ca}^{2+}$ independence of muscarinic enhancement of R-type VSCCS. In a CA1 pyramidal neuron recorded with $10 \mathrm{~mm}$ BAPTA-based intracellular solution, the R-type $\mathrm{Ca}^{2+}$ current is enhanced in carbachol (1, Control; 2, CCH). B, C, A Ca ${ }^{2+}$-independent PKC pathway is involved in the muscarinic modulation of R-type VSCCs (1, Control; 2, CCH). B, Preincubation of the broad spectrum PKC blocker GF $109203 x(10 \mu \mathrm{M})$ abolishes the muscarinic stimulation of R-type $\mathrm{Ca}^{2+}$ currents and, conversely, results in current depression. $C$, After preincubation of the group I PKC $\left(\mathrm{Ca}^{2+}\right.$ dependent isoforms) inhibitor Go $6976(10 \mu \mathrm{M})$, the muscarinic stimulation of R-type VSCCs is not affected. $\boldsymbol{D}$, Mean data for the effects of intracellular solutions containing either $1.1 \mathrm{~mm}$ EGTA or $10 \mathrm{~mm}$ BAPTA on the muscarinic enhancement of R-type VSCCS. $\boldsymbol{E}$, Mean data for the effects of GF 109203x (10 $\mu \mathrm{M}$ ), Ro 31-8220 (10 $\mu$ m; broad spectrum PKC blocker), G0 6976 (10 $\mu \mathrm{M}), \mathrm{KN}-93$ (10 $\mu \mathrm{m}$; CaMKII blocker), and PP2 (10 $\mu \mathrm{m}$; Src tyrosine kinase inhibitor) on the muscarinic modulation of R-type VSCCs (for each group, $n \geq 5$ ). All recordings were obtained in TTX and VSCC blockers (as described in Materials and Methods). Error bars indicate the mean \pm SEM. Asterisk indicates significant change $\left({ }^{*} p<0.001\right)$. 
rons in TTX without a blocking of any $\mathrm{Ca}^{2+}$ currents, large-amplitude prolonged plateau $\mathrm{Ca}^{2+}$ spikes were evoked by injection of brief $(40 \mathrm{~ms})$ intracellular current pulses $(n=7)$ (Fig. 6A,B). Carbachol depressed the plateau $\mathrm{Ca}^{2+}$ spikes, consistent with a muscarinic depression of L-, $\mathrm{N}$-, and P/Q-type VSCCs, leaving only a transient $\mathrm{HVA} \mathrm{Ca}^{2+}$ spike. A significant portion of this calcium spike in carbachol could be attributable to R-type $\mathrm{Ca}^{2+}$ currents, because it was $\mathrm{Ni}^{2+}$-sensitive $(n=$ 4). These results suggest that muscarinic receptor activation in hippocampal neurons could shift the normal pattern of $\mathrm{Ca}^{2+}$ entry from the slowly inactivating $\mathrm{N}-$, P/Q-, and L-type VSCCs to domination by the HVA rapidly inactivating R-type VSCCs.

To delineate rigorously the direct action of carbachol on the toxin-resistant $\mathrm{Ca}^{2+}$ spikes, we isolated them with a mixture containing TTX, nifedipine, and toxins, as shown in previous voltage-clamp experiments. Under these conditions depolarization of neurons with intracellular current injection often led to the generation of a transient $\mathrm{HVA} \mathrm{Ca}^{2+}$ spike $(n=$ 50 of 69 ). The $\mathrm{Ca}^{2+}$ spike inactivated during the depolarizing command pulses, consistent with a $\mathrm{Ca}^{2+}$ spike mediated by rapidly inactivating HVA R-type $\mathrm{Ca}^{2+}$ currents (Randall and Tsien, 1997). However, even with strong current injection $(\geq 0.5 \mathrm{nA})$ numerous cells $(28 \% ; n=19$ of 69) remained silent. As shown previously with current-clamp recordings (Kuzmiski et al., 2005), subsequent bath application of carbachol resulted in persistent enhancement of R-type $\mathrm{Ca}^{2+}$ spiking in both the spiking and initially silent neurons (Fig. 6C,D). The initially silent neurons exhibited transient $\mathrm{Ca}^{2+}$ spikes in the presence of carbachol $(n=19)$ (Fig. 6C,D). In neurons that initially showed an R-type $\mathrm{Ca}^{2+}$ spike, carbachol induced an increase in spike amplitude $\left(\Delta A P_{\mathrm{AMP}}=5.7 \pm 0.7 \mathrm{mV} ; p<0.0001 ; n=\right.$ $50)$, a decrease in the threshold for spike activation $\left(\Delta A P_{\mathrm{TH}}=\right.$ $-6.7 \pm 0.8 \mathrm{mV} ; p<0.0001 ; n=50)$, and a reduction in the current injection required to evoke a spike $(\Delta I=-80 \pm 12 \mathrm{pA}$; $p<0.0001 ; n=50$ ) (Fig. $6 F$ ). These enhanced spikes were blocked by the application of $\mathrm{Ni}^{2+}(50 \mu \mathrm{M} ; n=20)$ (Fig. $6 E, G, H)$, which at this concentration is selective for R- and T-type VSCCs. This enhancement was not caused by a muscarinic-mediated increase in input resistance $\left(R_{\mathrm{IN}}\right)$ (control $R_{\mathrm{IN}}, 115.7 \pm 5.9 \mathrm{M} \Omega$ vs carbachol $R_{\mathrm{IN}}, 118.0 \pm 6.1 \mathrm{M} \Omega ; p=0.77$; $n=69)$. The application of high concentrations of nimodipine (20 $\mu \mathrm{M})$ sufficient to block partially the T-type VSCCs had no effect on the carbachol-enhanced HVA $\mathrm{Ca}^{2+}$ spikes (percentage of $\Delta A P_{\mathrm{AMP}}, 3.5 \pm 2.6 \% ; p=0.25$; percentage of $\Delta d V_{\mathrm{m}} / d t_{\mathrm{max}}$, $-5.2 \pm 9.1 \% ; p=0.38 ; n=5$ ) (Fig. $6 G, H)$. In addition, the $\mathrm{Ca}^{2+}$ spikes were only weakly voltage dependent when held at depolarized voltages (from -70 to $-60 \mathrm{mV}$ ) (percentage of $\triangle A P_{\mathrm{AMP}}$,
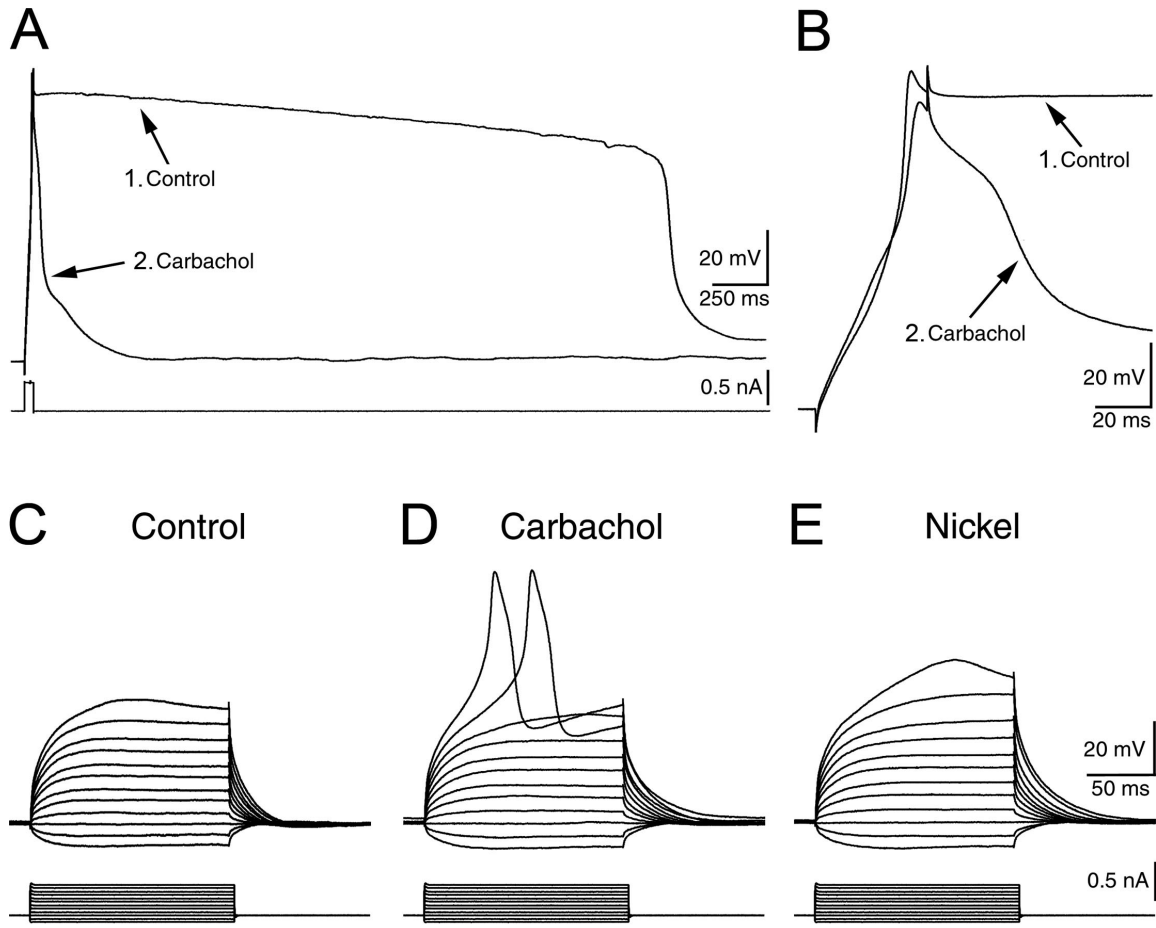

E Nickel
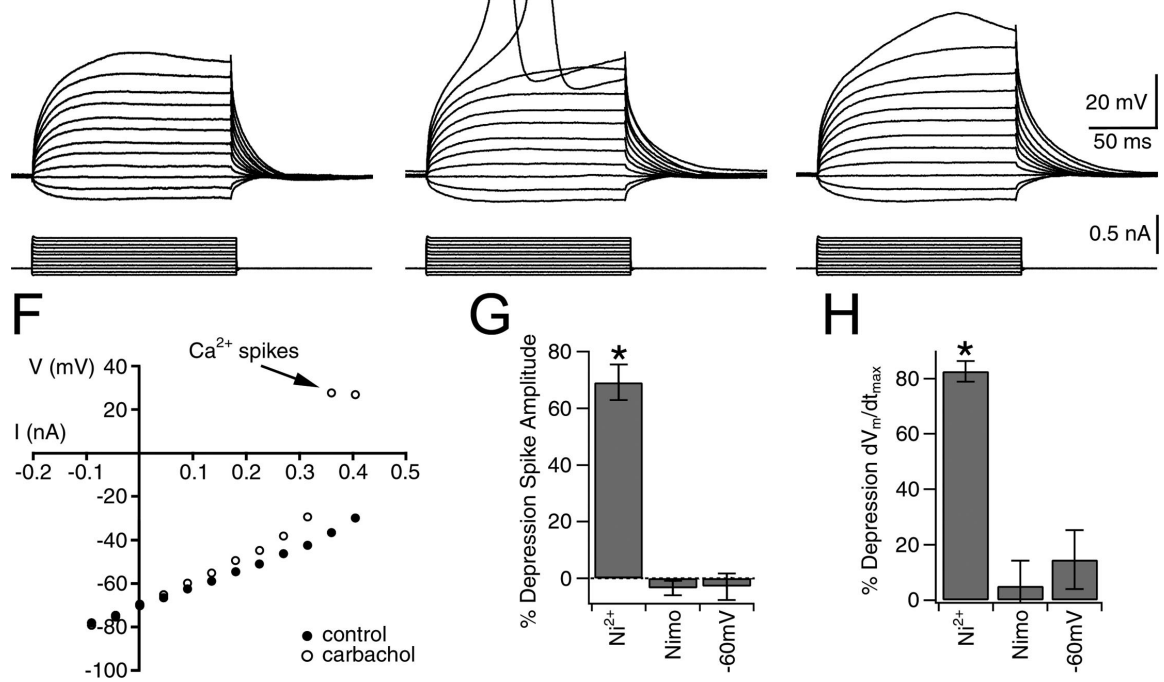

Figure 6. R-type VSCC-dependent spikes are enhanced by carbachol. $A, \mathrm{Ca}^{2+}$ spikes evoked by current injection before (1, Control) and after (2) carbachol application. $\boldsymbol{B}$, Expanded view of $\mathrm{Ca}^{2+}$ spikes in $\boldsymbol{A}$ before (1, Control) and after (2) carbachol in Activation of R-type VSCC-dependent spikes is observed only after the application of carbachol. $E$, Application of $50 \mu \mathrm{M} \mathrm{Ni}{ }^{2+}$ R-type VSCC blocker) depresses carbachol-enhanced R-type $\mathrm{Ca}^{2+}$ spikes. $\boldsymbol{F}$, Plot of $I-V$ relationship before and after carbachol. -type VSCC blocker; $n=5)$, and membrane depolarization to $-60 \mathrm{mV}(n=5)$ on the peak amplitude or the maximum rate of rise $\left(d V_{\mathrm{m}} / d t_{\text {max }}\right)$ of the carbachol-enhanced R-type $\mathrm{Ca}^{2+}$ spikes as compared with spikes evoked in carbachol. Error bars indicate the mean \pm SEM. Asterisk indicates significant depression $\left({ }^{*} p<0.001\right)$.

$2.9 \pm 4.8 \% ; p=0.82$; percentage of $\Delta d V_{\mathrm{m}} / d t_{\max },-14.6 \pm 10.6 \%$; $p=0.24 ; n=5$ ) (Fig. $6 G, H)$. Consistent with our voltage-clamp results, we concluded that R-type, but not T-type, $\mathrm{Ca}^{2+}$ currents generated the toxin-resistant $\mathrm{Ca}^{2+}$ spikes.

\section{Muscarinic enhancement of R-type $\mathrm{Ca}^{2+}$ spikes contributes to carbachol-induced theta burst oscillations}

The cholinergic system is implicated in the generation of theta both in vitro and in vivo (Buzsaki, 2002). During theta in vivo the HVA Ca ${ }^{2+}$ spikes oscillate rhythmically at theta frequencies in the dendrites of CA1 pyramidal neurons and may contribute to current generation and amplification of theta (Kamondi et al., 1998; Buzsaki, 2002). However, the VSCC subtypes that contribute to dendritic oscillations during theta are unknown. We examined the possibility that muscarinic-enhanced R-type $\mathrm{Ca}^{2+}$ spikes can resonate at theta frequency and thereby contribute to the generation of dendritic oscillations. To evaluate the firing 
A

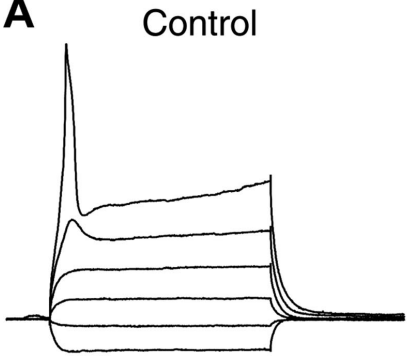

C

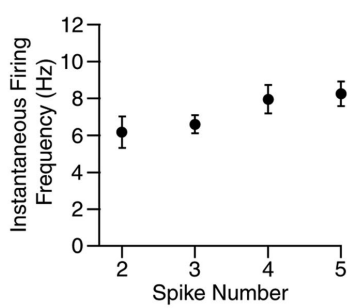

B

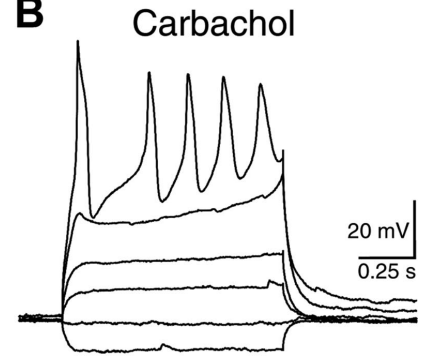

D 4-AP + Linopirdine

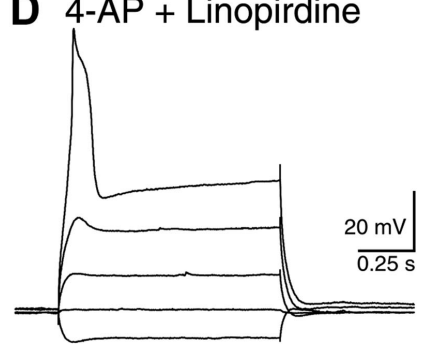

Figure 7. Muscarinic-enhanced $\mathrm{R}$-type $\mathrm{Ca}^{2+}$ spikes fire repetitively at theta frequency. $\boldsymbol{A}$, R-type $\mathrm{Ca}^{2+}$ spike evoked by injection of a long (1.0 s) depolarizing current pulse. $\boldsymbol{B}$, Repetitive R-type $\mathrm{Ca}^{2+}$ spiking evoked during a long current pulse after the application of carbachol. $C$, Instantaneous firing frequency of repetitive R-type $\mathrm{Ca}^{2+}$ spikes after carbachol treatment $(n=$ 11). Error bars indicate the mean \pm SEM. $D$, Application of $5 \mathrm{~mm} 4-\mathrm{AP}\left(\mathrm{K}^{+}\right.$channel blocker) and 10 $\mu \mathrm{M}$ linopirdine (M-current blocker) failed to induce the repetitive R-type $\mathrm{Ca}^{2+}$ spiking $(n=3)$.

frequencies of R-type $\mathrm{Ca}^{2+}$ spikes, we injected long (0.5-1.0 s) depolarizing steps of current in neurons in the presence of TTX, VSCC toxins, and nifedipine as described above. Under these conditions either the cells were silent or only a single spike could be evoked even with strong current injection (Fig. 7A). After the addition of carbachol to the perfusate, $\mathrm{R}$-type $\mathrm{Ca}^{2+}$ spiking was enhanced, and now multiple spikes could be evoked (Fig. 7B). Interestingly, repetitive $\mathrm{R}$-type $\mathrm{Ca}^{2+}$ spiking displayed a regular rhythm in the theta frequency range $(6-9 \mathrm{~Hz} ; n=11)$ (Fig. $7 C)$. Application of $\mathrm{K}^{+}$channel blockers (4-AP, $5 \mathrm{~mm}$; linopirdine, 10 $\mu \mathrm{M})$ failed to mimic this repetitive firing pattern $(n=3)$ (Fig. $7 D$ ), suggesting that the ability of the R-type $\mathrm{Ca}^{2+}$ spikes to fire at theta frequency is attributable to direct actions on R-type VSCCs. To avoid the generation of plateau potentials (Fraser and MacVicar, 1996), we limited our recordings to $<1 \mathrm{~s}$. These findings indicate that carbachol-enhanced $\mathrm{R}$-type $\mathrm{Ca}^{2+}$ spiking could contribute to the intrinsic resonant depolarizations of CA1 pyramidal neurons in the theta frequency.

To examine the potential contribution of muscarinicenhanced R-type VSCCs to theta burst oscillatory activity, we also recorded spontaneous extracellular events from area CA1. In the majority of naive hippocampal slices the theta frequency oscillations were generated after continuous bath application of carbachol (Fig. $8 \mathrm{~A}$ ). Field potential recordings showed a peak power spectra of $0.016 \pm 0.0071 \mathrm{mV}^{2} / \mathrm{Hz}$ at a mean frequency of $8.3 \pm$ $0.6 \mathrm{~Hz}(n=8)$ (Fig. $8 \mathrm{~B})$. The spontaneous oscillatory bursts occurred at regular intervals of $101.4 \pm 10.9 \mathrm{~s}(n=8)$ and lasted for $21.4 \pm 2.6 \mathrm{~s}$. Theta burst oscillations closely resembled those previously described (Bland et al., 1988). Subsequent application of a low concentration of $\mathrm{Ni}^{2+}$ depressed the oscillatory activity, as shown by an almost complete abolition of the power in the theta frequency range $(n=8$ of 8 ) (Fig. $8 A, B)$. In five of eight slices the oscillatory bursts were abolished completely. In the other three slices $\mathrm{Ni}^{2+}$ reduced the amplitude of the theta burst oscillations and increased the interburst interval without signifi- cant effects on burst durations $(19.3 \pm 2.8 \mathrm{~s} ; n=3)$ or the frequency of the oscillations $(8.3 \pm 0.4 \mathrm{~Hz})$. Disruption of the theta bursts often was accompanied by a change in the field events to a slower, more interictal-like pattern. Because we demonstrated that T-type VSCCs are not affected by cholinergic stimulation, these results suggest that $\mathrm{Ni}^{2+}$ suppressed the carbachol-induced spontaneous field potential theta oscillations by depressing R-type VSCCs. Therefore, our results indicate that in CA1 pyramidal neurons the enhancement of R-type VSCCs could contribute to muscarinic-induced theta frequency oscillations.

\section{Discussion}

Our results show that muscarinic activation stimulates R-type $\mathrm{Ca}^{2+}$ currents in hippocampal CA1 neurons that can lead to de novo activation of R-type dependent $\mathrm{Ca}^{2+}$ spikes. This enhancement likely is mediated via a $\mathrm{Ca}^{2+}$-independent $\mathrm{PKC}$ pathway because it is blocked by broad spectrum inhibitors to $\mathrm{PKC}$, but not by an inhibitor of $\mathrm{Ca}^{2+}$-dependent $\mathrm{PKC}$, and it is insensitive to chelation of intracellular $\mathrm{Ca}^{2+}$ by BAPTA. In contrast to the enhancement of the R-type currents, T-type $\mathrm{Ca}^{2+}$ currents were not modulated by muscarinic receptor activation. The muscarinic-mediated enhancement of transient R-type $\mathrm{Ca}^{2+}$ spikes resulted in remarkable changes in the firing pattern of R-type $\mathrm{Ca}^{2+}$ spikes and could contribute to theta oscillations.

\section{Mechanisms underlying muscarinic enhancement of R-type VSCCs}

R-type $\mathrm{Ca}^{2+}$ currents in hippocampal neurons are attributable mainly to $\mathrm{Ca}_{\mathrm{V}} 2.3$ subunits (Sochivko et al., 2002, 2003), although there is still some controversy as to the proportion of R-type $\mathrm{Ca}^{2+}$ currents that remains in the $\mathrm{Ca}_{\mathrm{V}} 2.3$ knock-out mouse (Wilson et al., 2000). In recombinant systems $\mathrm{Ca}_{\mathrm{V}} 2.3$ subunit $\mathrm{Ca}^{2+}$ currents are enhanced by $\mathrm{G} \alpha_{\mathrm{q} / 11}$-coupled muscarinic receptor activation (Bannister et al., 2004; Kamatchi et al., 2004). Here we show a similar enhancement of R-type $\mathrm{Ca}^{2+}$ currents in hippocampal neurons also mediated by muscarinic $M_{1} / M_{3}$ receptor stimulation. Hippocampal pyramidal neurons express high levels of postsynaptic $M_{1}$ and $M_{3}$ receptors (Vilaro et al., 1993; Levey et al., 1995; Rouse et al., 1999). These receptors are $\mathrm{G} \alpha_{\mathrm{q} / 11}$ coupled, and their activation results in the generation of $\mathrm{DAG}$ and $\mathrm{IP}_{3}$ via $\mathrm{PLC}$ activation. DAG and $\mathrm{IP}_{3}$ in turn activate $\mathrm{PKC}$ and $\mathrm{IP}_{3}$ receptor pathways, respectively. Similar to previous work in HEK cells and Xenopus oocytes (Bannister et al., 2004; Kamatchi et al., 2004), the muscarinic stimulation of R-type VSCCs in hippocampal neurons was independent of intracellular $\mathrm{Ca}^{2+}$ and required the activation of $\mathrm{Ca}^{2+}$-independent group II PKCs. All three groups of PKCs are expressed in rat hippocampus (Naik et al., 2000), and PKC $\delta$ from among the group II PKCs $(\delta, \varepsilon, \eta$, and $\theta)$ may be the isoform of PKC that is involved. PKC $\delta$ is highly expressed in rat hippocampal CA1 pyramidal neurons (McNamara et al., 1999; Tang et al., 2004), and in response to muscarinic stimulation PKC $\delta$ is activated and translocated to plasma membrane (Brown et al., 2005). In recombinant systems the coexpression of a dominant-negative PKC $\delta$ blocked the muscarinic stimulation of $\mathrm{Ca}_{\mathrm{V}} 2.3$ subunits, whereas the blocker of PKC $\varepsilon$ could not (Bannister et al., 2004). However, we could not rule out definitively the contribution of other isoforms. In PKC inhibitors we observed a suppression of R-type $\mathrm{Ca}^{2+}$ currents by muscarinic stimulation, suggesting other inhibitory pathways. This inhibition may result from the activation of pertussis toxinsensitive G-protein-coupled $\mathrm{M}_{2} / \mathrm{M}_{4}$ receptors and $\mathrm{G} \beta \gamma$ subunitmediated inhibition (Meza et al., 1999; Bannister et al., 2004). 
R-type versus other VSCC types

Muscarinic enhancement of R-type VSCCs is strikingly opposite to muscarinic depression of all other HVA VSCCs (Ntype, P-/Q-type, and L-type) (Gahwiler and Brown, 1987; Shapiro et al., 1999, 2001; Stewart et al., 1999). Christie and colleagues (1995) showed that in the soma and basal dendrites $(\leq 50 \mu \mathrm{m})$ all of the HVA VSCCs as well as LVA VSCCs contribute to spike-triggered $\mathrm{Ca}^{2+}$ entry. In contrast, T-type and $\mathrm{Ni}^{2+}$-sensitive R-type VSCCs predominantly underlie spike-triggered $\mathrm{Ca}^{2+}$ entry in apical dendrites $(\geq 100 \mu \mathrm{m})$ (Christie et al., 1995). Single channel analysis also shows that all VSCC types are expressed in the soma, whereas in dendrites T- and R-type VSCCs predominate (Magee and Johnston, 1995). Action potential or depolarizationinduced $\mathrm{Ca}^{2+}$ influx in dendrites and spines also has been shown to be mediated mainly by R-type VSCCs (Sabatini and Svoboda, 2000; Yasuda et al., 2003). The distinct distribution in apical dendrites and the unique modulation of R-type VSCCs suggest that they play a different role and underlie distinct cellular functions from other types of VSCCs, such as synaptic integration and plasticity.

Despite the general suppression of $\mathrm{Ca}^{2+}$ currents, muscarinic activation paradoxically increases intracellular $\mathrm{Ca}^{2+}$ accumulations in the dendrites and spines from depolarization or synaptic stimulation (Muller and Connor, 1991, 1992; Tsubokawa and Ross, 1997; Beier and Barish, 2000). $\mathrm{K}^{+}$conductance blockade and the $\mathrm{IP}_{3}$-mediated release of $\mathrm{Ca}^{2+}$ from intracellular stores are thought to contribute to this accumulation (Muller and Connor, 1991, 1992; Tsubokawa and Ross, 1997; Beier and Barish, 2000). However, our results suggest that the stimulation of $\mathrm{R}$-type $\mathrm{Ca}^{2+}$ currents also might contribute to the muscarinicmediated intracellular $\mathrm{Ca}^{2+}$ accumulations.

All three T-type VSCC subunits $(\alpha 1 \mathrm{G}, \alpha 1 \mathrm{H}$, and $\alpha 1 \mathrm{I})$ are expressed in hippocampal pyramidal neurons (Talley et al., 1999). However, their modulation and functional impact on hippocampal pyramidal neurons are not yet known. Compared with HVA channels, T-type VSCCs are more metabolically stable and are less likely to be modulated (Huang et al., 2005). Muscarinic activation has been reported to increase, decrease, or not affect the T-type $\mathrm{Ca}^{2+}$ currents, depending on the cell type and experimental conditions (Yunker, 2003). In the present study T-type $\mathrm{Ca}^{2+}$ currents in hippocampal pyramidal neurons were not affected by muscarinic stimulation.

Muscarinic stimulation is known to suppress $\mathrm{K}^{+}$channels, such as M channels (Brown and Adams, 1980; Halliwell and Adams, 1982), thereby enhancing neuronal excitability. However, in the present study the enhancement of R-type $\mathrm{Ca}^{2+}$ currents is not attributable to $\mathrm{K}^{+}$channel depression. High concentrations of potassium channel blockers were applied both intracellularly and extracellularly (see Materials and Methods), and most $\mathrm{K}^{+}$currents were observed to be blocked. When the $\mathrm{HVA} \mathrm{Ca}^{2+}$ currents were blocked first with $\mathrm{Cd}^{2+}(1 \mathrm{~mm})$, muscarinic activation did not affect the residue $\mathrm{K}^{+}$currents (data not shown). In addition, the repetitive R-type $\mathrm{Ca}^{2+}$ spike firing we observed in carbachol was not elicited with $\mathrm{K}^{+}$channel inhibitors. Furthermore, T-type $\mathrm{Ca}^{2+}$ currents were found to be unaltered by carbachol application. Under normal physiological conditions it is likely that the suppression of $\mathrm{K}^{+}$channels and enhancement of R-type VSCCs both contribute to the muscarinic stimulation of neuronal excitability.

A concern for this type of study is the possibility of poor voltage control during voltage-clamp experiments. To achieve well clamped currents, we applied high concentrations of $\mathrm{K}^{+}$ channel blockers both intracellularly and extracellularly (Colino and Halliwell, 1993), and we used younger animals (13-16 d) so that the calcium currents would be smaller and the dendritic processes less extensive. Also, large electrode tips were used (3-5 $\mathrm{M} \Omega$ ), and only cells with access resistances $<20 \mathrm{M} \Omega$ were included in the study. The voltage clamp appeared to be sufficient in most experiments because there was a graded turn-on of the currents, and channel activation properties of the currents were similar to those observed in acutely isolated neurons (Foehring et al., 2000; Sochivko et al., 2003).

\section{R-type spikes and theta oscillations}

Muscarinic receptor stimulation in the hippocampus in vitro generates robust oscillations, which share a common frequency with theta rhythm observed in vivo. The activation of oscillatory intrinsic conductances contributes importantly to theta current generation (Buzsaki, 2002). Voltage-dependent oscillations have been described in the somata (Leung and Yim, 1991) and dendrites of pyramidal neurons (Kamondi et al., 1998). During theta induction the somatic membrane hyperpolarizes, whereas den- 
drites depolarize. When the dendritic depolarization is sufficiently strong, the resonant property of the membrane leads to a HVA $\mathrm{Ca}^{2+}$ spike-dependent self-sustained oscillation in the theta frequency range (Kamondi et al., 1998). Nickel ions selectively abolish dendritic calcium spikes via blocking R- and/or T-type VSCCs (Gillies et al., 2002; Isomura et al., 2002). Here we have demonstrated that carbachol-enhanced, $\mathrm{Ni}^{2+}$-sensitive $\mathrm{R}$-type $\mathrm{Ca}^{2+}$ spikes can fire repetitively at theta frequencies. Given that T-type VSCCs are not affected by carbachol, our results suggest that R-type VSCCs contribute to the amplification of the theta oscillations.

Based on pharmacological sensitivity, two types of theta could be distinguished: atropine-sensitive and atropine-resistant ( Kramis et al., 1975; Buzsaki, 2002). Our results show that $\mathrm{Ni}^{2+}$ blocked carbachol-induced spontaneous theta burst oscillations. This agrees with a previous study demonstrating that $\mathrm{Ni}^{2+}(100$ $\mu \mathrm{M})$ blocked mGluR-activated but atropine-resistant theta oscillations (Gillies et al., 2002). In this previous study $\mathrm{Ni}^{2+}$ dependent spikes were generated in the distal dendrites at theta frequencies. We found that the mGluR agonists trans-ACPD (trans-1-aminocyclopentane-1,3-dicarboxylic acid; $50 \mu \mathrm{M}$ ) and DHPG (dihydrophenylglycol; $50 \mu \mathrm{M}$ ) resulted in enhanced R-type $\mathrm{Ca}^{2+}$ spiking similar to that observed with carbachol (data not shown) (Kuzmiski and MacVicar, 2003). These results suggested that a similar contribution of R-type VSCCs to both atropine-sensitive and atropine-resistant forms of theta might exist.

In the hippocampus $\mathrm{Ca}^{2+}$ spikes are generated during highly synchronous excitatory input that is associated with behavior in vivo. The ability of carbachol-enhanced R-type $\mathrm{Ca}^{2+}$ spikes to resonate at theta frequencies suggests that it is an intrinsic property of the neuronal membrane that plays a key role in the generation of neuronal network oscillations. The resonance property of R-type VSCCs also may be important for synaptic plasticity induced by theta burst stimulation (Ito et al., 1995), the enhanced induction of theta during cholinergic stimulation (Huerta and Lisman, 1993), and the formation of accurate spatial memory (Kubota et al., 2001).

\section{References}

Avery RB, Johnston D (1996) Multiple channel types contribute to the lowvoltage-activated calcium current in hippocampal CA3 pyramidal neurons. J Neurosci 16:5567-5582.

Bannister RA, Melliti K, Adams BA (2004) Differential modulation of $\mathrm{Ca}_{\mathrm{v}} 2.3 \mathrm{Ca}^{2+}$ channels by $\mathrm{G} \alpha \mathrm{q} / 11$-coupled muscarinic receptors. Mol Pharmacol 65:381-388.

Beier SM, Barish ME (2000) Cholinergic stimulation enhances cytosolic calcium ion accumulation in mouse hippocampal CA1 pyramidal neurones during short action potential trains. J Physiol (Lond) 526[Pt 1]:129-142.

Bland BH, Colom LV, Konopacki J, Roth SH (1988) Intracellular records of carbachol-induced theta rhythm in hippocampal slices. Brain Res 447:364-368.

Blanton MG, Lo Turco JJ, Kriegstein AR (1989) Whole cell recording from neurons in slices of reptilian and mammalian cerebral cortex. J Neurosci Methods 30:203-210.

Breustedt J, Vogt KE, Miller RJ, Nicoll RA, Schmitz D (2003) $\alpha_{1 E^{-}}$ containing $\mathrm{Ca}^{2+}$ channels are involved in synaptic plasticity. Proc Natl Acad Sci USA 100:12450-12455.

Brown DA, Adams PR (1980) Muscarinic suppression of a novel voltagesensitive $\mathrm{K}^{+}$current in a vertebrate neurone. Nature 283:673-676.

Brown SG, Thomas A, Dekker LV, Tinker A, Leaney JL (2005) PKC- $\delta$ sensitizes Kir3.1/3.2 channels to changes in membrane phospholipid levels after $\mathrm{M}_{3}$ receptor activation in HEK-293 cells. Am J Physiol Cell Physiol 289:C543-C556.

Buzsaki G (2002) Theta oscillations in the hippocampus. Neuron $33: 325-340$
Christie BR, Eliot LS, Ito K, Miyakawa H, Johnston D (1995) Different Ca ${ }^{2+}$ channels in soma and dendrites of hippocampal pyramidal neurons mediate spike-induced $\mathrm{Ca}^{2+}$ influx. J Neurophysiol 73:2553-2557.

Colino A, Halliwell JV (1993) Carbachol potentiates Q current and activates a calcium-dependent non-specific conductance in rat hippocampus in vitro. Eur J Neurosci 5:1198-1209.

Dietrich D, Kirschstein T, Kukley M, Pereverzev A, von der Brelie C, Schneider T, Beck H (2003) Functional specialization of presynaptic $\mathrm{Ca}_{\mathrm{V}} 2.3$ $\mathrm{Ca}^{2+}$ channels. Neuron 39:483-496.

Foehring RC, Mermelstein PG, Song WJ, Ulrich S, Surmeier DJ (2000) Unique properties of R-type calcium currents in neocortical and neostriatal neurons. J Neurophysiol 84:2225-2236.

Fraser DD, MacVicar BA (1996) Cholinergic-dependent plateau potential in hippocampal CA1 pyramidal neurons. J Neurosci 16:4113-4128.

Gahwiler BH, Brown DA (1987) Muscarine affects calcium currents in rat hippocampal pyramidal cells in vitro. Neurosci Lett 76:301-306.

Gillies MJ, Traub RD, LeBeau FE, Davies CH, Gloveli T, Buhl EH, Whittington MA (2002) A model of atropine-resistant theta oscillations in rat hippocampal area CA1. J Physiol (Lond) 543:779-793.

Grishin AA, Benquet P, Gerber U (2005) Muscarinic receptor stimulation reduces NMDA responses in CA3 hippocampal pyramidal cells via $\mathrm{Ca}^{2+}$ dependent activation of tyrosine phosphatase. Neuropharmacology 49:328-337.

Halliwell JV, Adams PR (1982) Voltage-clamp analysis of muscarinic excitation in hippocampal neurons. Brain Res 250:71-92.

Huang CS, Shi SH, Ule J, Ruggiu M, Barker LA, Darnell RB, Jan YN, Jan LY (2005) Common molecular pathways mediate long-term potentiation of synaptic excitation and slow synaptic inhibition. Cell 123:105-118.

Huerta PT, Lisman JE (1993) Heightened synaptic plasticity of hippocampal CA1 neurons during a cholinergically induced rhythmic state. Nature 364:723-725.

Huguenard JR (1996) Low-threshold calcium currents in central nervous system neurons. Annu Rev Physiol 58:329-348.

Isomura Y, Fujiwara-Tsukamoto Y, Imanishi M, Nambu A, Takada M (2002) Distance-dependent $\mathrm{Ni}^{2+}$ sensitivity of synaptic plasticity in apical dendrites of hippocampal CA1 pyramidal cells. J Neurophysiol 87:1169-1174.

Ito K, Miura M, Furuse H, Zhixiong C, Kato H, Yasutomi D, Inoue T, Mikoshiba K, Kimura T, Sakakibara S (1995) Voltage-gated $\mathrm{Ca}^{2+}$ channel blockers, omega-AgaIVA and $\mathrm{Ni}^{2+}$, suppress the induction of theta-burst induced long-term potentiation in guinea-pig hippocampal CAl neurons. Neurosci Lett 183:112-115.

Kamatchi GL, Franke R, Lynch 3rd C, Sando JJ (2004) Identification of sites responsible for potentiation of type 2.3 calcium currents by acetyl- $\beta$ methylcholine. J Biol Chem 279:4102-4109.

Kamondi A, Acsady L, Wang XJ, Buzs $\leftrightarrow$ ki G (1998) Theta oscillations in somata and dendrites of hippocampal pyramidal cells in vivo: activitydependent phase-precession of action potentials. Hippocampus 8:244-261.

Klockner U, Lee JH, Cribbs LL, Daud A, Hescheler J, Pereverzev A, PerezReyes E, Schneider T (1999) Comparison of the $\mathrm{Ca}^{2+}$ currents induced by expression of three cloned $\alpha 1$ subunits, $\alpha 1 \mathrm{G}, \alpha 1 \mathrm{H}$, and $\alpha 1 \mathrm{I}$, of lowvoltage-activated T-type $\mathrm{Ca}^{2+}$ channels. Eur J Neurosci 11:4171-4178.

Kramis R, Vanderwolf CH, Bland BH (1975) Two types of hippocampal rhythmical slow activity in both the rabbit and the rat: relations to behavior and effects of atropine, diethyl ether, urethane, and pentobarbital. Exp Neurol 49:58-85.

Kubota M, Murakoshi T, Saegusa H, Kazuno A, Zong S, Hu Q, Noda T, Tanabe T (2001) Intact LTP and fear memory but impaired spatial memory in mice lacking $\mathrm{Ca}_{\mathrm{V}} 2.3\left(\alpha_{\mathrm{IE}}\right)$ channel. Biochem Biophys Res Commun 282:242-248.

Kuzmiski JB, MacVicar BA (2001) Cyclic nucleotide-gated channels contribute to the cholinergic plateau potential in hippocampal CA1 pyramidal neurons. J Neurosci 21:8707-8714.

Kuzmiski JB, MacVicar BA (2003) Muscarinic and metabotropic glutamate receptor enhanced R-type calcium spikes underlie theta oscillations in CA1 pyramidal neurons. Soc Neurosci Abstr 29:258.11.

Kuzmiski JB, Barr W, Zamponi GW, MacVicar BA (2005) Topiramate inhibits the initiation of plateau potentials in CA1 neurons by depressing R-type calcium channels. Epilepsia 46:481-489.

Lee JH, Gomora JC, Cribbs LL, Perez-Reyes E (1999) Nickel block of three 
cloned T-type calcium channels: low concentrations selectively block $\alpha 1$ H. Biophys J 77:3034-3042.

Leung LW, Yim CY (1991) Intrinsic membrane potential oscillations in hippocampal neurons in vitro. Brain Res 553:261-274.

Levey AI, Edmunds SM, Koliatsos V, Wiley RG, Heilman CJ (1995) Expression of $\mathrm{M}_{1}-\mathrm{M}_{4}$ muscarinic acetylcholine receptor proteins in rat hippocampus and regulation by cholinergic innervation. J Neurosci 15:4077-4092.

Magee JC, Carruth M (1999) Dendritic voltage-gated ion channels regulate the action potential firing mode of hippocampal CA1 pyramidal neurons. J Neurophysiol 82:1895-1901.

Magee JC, Johnston D (1995) Characterization of single voltage-gated $\mathrm{Na}^{+}$ and $\mathrm{Ca}^{2+}$ channels in apical dendrites of rat CAl pyramidal neurons. J Physiol (Lond) 487 [Pt 1]:67-90.

McNamara RK, Wees EA, Lenox RH (1999) Differential subcellular redistribution of protein kinase $\mathrm{C}$ isozymes in the rat hippocampus induced by kainic acid. J Neurochem 72:1735-1743.

Melliti K, Meza U, Adams B (2000) Muscarinic stimulation of $\alpha 1$ E Ca channels is selectively blocked by the effector antagonist function of RGS2 and phospholipase C- $\beta 1$. J Neurosci 20:7167-7173.

Metz AE, Jarsky T, Martina M, Spruston N (2005) R-type calcium channels contribute to afterdepolarization and bursting in hippocampal CA1 pyramidal neurons. J Neurosci 25:5763-5773.

Meza U, Bannister R, Melliti K, Adams B (1999) Biphasic, opposing modulation of cloned neuronal $\alpha 1 \mathrm{E}$ Ca channels by distinct signaling pathways coupled to $\mathrm{M}_{2}$ muscarinic acetylcholine receptors. J Neurosci 19:6806-6817.

Mogul DJ, Fox AP (1991) Evidence for multiple types of $\mathrm{Ca}^{2+}$ channels in acutely isolated hippocampal CA3 neurones of the guinea-pig. J Physiol (Lond) 433:259-281.

Muller W, Connor JA (1991) Cholinergic input uncouples $\mathrm{Ca}^{2+}$ changes from $\mathrm{K}^{+}$conductance activation and amplifies intradendritic $\mathrm{Ca}^{2+}$ changes in hippocampal neurons. Neuron 6:901-905.

Muller W, Connor JA (1992) $\mathrm{Ca}^{2+}$ signaling in postsynaptic dendrites and spines of mammalian neurons in brain slice. J Physiol (Paris) 86:57-66.

Naik MU, Benedikz E, Hernandez I, Libien J, Hrabe J, Valsamis M, DowEdwards D, Osman M, Sacktor TC (2000) Distribution of protein kinase $\mathrm{M} \zeta$ and the complete protein kinase $\mathrm{C}$ isoform family in rat brain. J Comp Neurol 426:243-258.

Ozawa S, Tsuzuki K, Iino M, Ogura A, Kudo Y (1989) Three types of voltage-dependent calcium current in cultured rat hippocampal neurons. Brain Res 495:329-336.

Perez-Reyes E (2003) Molecular physiology of low-voltage-activated T-type calcium channels [review]. Physiol Rev 83:117-161.

Piedras-Renteria ES, Tsien RW (1998) Antisense oligonucleotides against $\alpha 1 \mathrm{E}$ reduce R-type calcium currents in cerebellar granule cells. Proc Natl Acad Sci USA 95:7760-7765.

Randall AD, Tsien RW (1995) Pharmacological dissection of multiple types of $\mathrm{Ca}^{2+}$ channel currents in rat cerebellar granule neurons. J Neurosci 15:2995-3012.

Randall AD, Tsien RW (1997) Contrasting biophysical and pharmacological properties of T-type and R-type calcium channels. Neuropharmacology 36:879-893.
Rouse ST, Marino MJ, Potter LT, Conn PJ, Levey AI (1999) Muscarinic receptor subtypes involved in hippocampal circuits. Life Sci 64:501-509.

Sabatini BL, Svoboda K (2000) Analysis of calcium channels in single spines using optical fluctuation analysis. Nature 408:589-593.

Shapiro MS, Loose MD, Hamilton SE, Nathanson NM, Gomeza J, Wess J, Hille B (1999) Assignment of muscarinic receptor subtypes mediating G-protein modulation of $\mathrm{Ca}^{2+}$ channels by using knockout mice. Proc Natl Acad Sci USA 96:10899-10904.

Shapiro MS, Gomeza J, Hamilton SE, Hille B, Loose MD, Nathanson NM, Roche JP, Wess J (2001) Identification of subtypes of muscarinic receptors that regulate $\mathrm{Ca}^{2+}$ and $\mathrm{K}^{+}$channel activity in sympathetic neurons. Life Sci 68:2481-2487.

Sochivko D, Pereverzev A, Smyth N, Gissel C, Schneider T, Beck H (2002) The $\mathrm{Ca}_{\mathrm{V}} 2.3 \mathrm{Ca}^{2+}$ channel subunit contributes to R-type $\mathrm{Ca}^{2+}$ currents in murine hippocampal and neocortical neurones. J Physiol (Lond) 542:699-710.

Sochivko D, Chen J, Becker A, Beck H (2003) Blocker-resistant Ca ${ }^{2+}$ currents in rat CA1 hippocampal pyramidal neurons. Neuroscience 116:629-638.

Stea A, Soong TW, Snutch TP (1995) Determinants of PKC-dependent modulation of a family of neuronal calcium channels. Neuron 15:929-940.

Stewart AE, Yan Z, Surmeier DJ, Foehring RC (1999) Muscarine modulates $\mathrm{Ca}^{2+}$ channel currents in rat sensorimotor pyramidal cells via two distinct pathways. J Neurophysiol 81:72-84.

Talley EM, Cribbs LL, Lee JH, Daud A, Perez-Reyes E, Bayliss DA (1999) Differential distribution of three members of a gene family encoding low voltage-activated (T-type) calcium channels. J Neurosci 19:1895-1911.

Tang FR, Lee WL, Gao H, Chen Y, Loh YT, Chia SC (2004) Expression of different isoforms of protein kinase $\mathrm{C}$ in the rat hippocampus after pilocarpine-induced status epilepticus with special reference to CA1 area and the dentate gyrus. Hippocampus 14:87-98.

Tsubokawa H, Ross WN (1997) Muscarinic modulation of spike backpropagation in the apical dendrites of hippocampal CA1 pyramidal neurons. J Neurosci 17:5782-5791.

Vilaro MT, Mengod G, Palacios G, Palacios JM (1993) Receptor distribution in the human and animal hippocampus: focus on muscarinic acetylcholine receptors. Hippocampus 3[Spec No]:149-156.

Wilson SM, Toth PT, Oh SB, Gillard SE, Volsen S, Ren D, Philipson LH, Lee EC, Fletcher CF, Tessarollo L, Copeland NG, Jenkins NA, Miller RJ (2000) The status of voltage-dependent calcium channels in $\alpha_{1 \mathrm{E}}$ knockout mice. J Neurosci 20:8566-8571.

Yasuda R, Sabatini BL, Svoboda K (2003) Plasticity of calcium channels in dendritic spines. Nat Neurosci 6:948-955.

Yunker AM (2003) Modulation and pharmacology of low voltage-activated ("T-type") calcium channels. J Bioenerg Biomembr 35:577-598.

Zhang JF, Randall AD, Ellinor PT, Horne WA, Sather WA, Tanabe T, Schwarz TL, Tsien RW (1993) Distinctive pharmacology and kinetics of cloned neuronal $\mathrm{Ca}^{2+}$ channels and their possible counterparts in mammalian CNS neurons. Neuropharmacology 32:1075-1088.

Zhao W, Bianchi R, Wang M, Wong RK (2004) Extracellular signalregulated kinase $1 / 2$ is required for the induction of group I metabotropic glutamate receptor-mediated epileptiform discharges. J Neurosci 24: $76-84$. 